Portland State University

PDXScholar

5-28-2019

\title{
How Schools Encourage Incarceration: The School- to-Prison Pipeline and How It Fails Our Children
}

Madeline S. Buss

Portland State University

Follow this and additional works at: https://pdxscholar.library.pdx.edu/honorstheses

Let us know how access to this document benefits you.

Recommended Citation

Buss, Madeline S., "How Schools Encourage Incarceration: The School-to-Prison Pipeline and How It Fails Our Children" (2019). University Honors Theses. Paper 767.

https://doi.org/10.15760/honors.785

This Thesis is brought to you for free and open access. It has been accepted for inclusion in University Honors Theses by an authorized administrator of PDXScholar. Please contact us if we can make this document more accessible: pdxscholar@pdx.edu. 
Portland State University

PDXScholar

University Honors Theses

University Honors College

\section{How Schools Encourage Incarceration: The School-to-Prison Pipeline and How It Fails Our Children}

Madeline S. Buss

Let us know how access to this document benefits you.

Follow this and additional works at: https://pdxscholar.library.pdx.edu/honorstheses

This Thesis is brought to you for free and open access. It has been accepted for inclusion in University Honors Theses by an authorized administrator of PDXScholar. For more information, please contact pdxscholar@pdx.edu. 
How Schools Encourage Incarceration: The School-to-Prison Pipeline and How It Fails Our Children

by

Madeline Buss

An undergraduate Honors Thesis submitted in partial fulfillment of the requirements for the degree of

Bachelor of Arts

in

University Honors

and

Criminology and Criminal Justice

\author{
Thesis Advisor \\ Carma Corcoran, Chippewa-Cree, $\mathrm{PhD}$
}

University Honors College

Portland State University

Spring Term 2019 


\begin{abstract}
:
In the United States, mass incarceration is a way of life. In this literature review, the link between harsh policies in schools, punishment, and later odds of incarceration are explored- with a special interest on the disproportionate impact for students of color. Through literature reviews and analysis, I will examine the primary causes of the schoolto-prison pipeline (STPP). The researchers examined spanned many disciplines (education, to criminology, to psychology) and methodological approaches, including qualitative, quantitative, and mixed-method. The findings were near unanimous; policies in schools that sought to punish or enforce zero-tolerance were disproportionately punitive toward students of color, most notably Black students. In an effort to mitigate this, most studies found that educating teachers and administrators on implicit bias and empathy-based corrections found a dramatic decrease in punishments being delivered, with the largest percentage change being with Black students. My thesis ends with a close look at a few local programs working to mitigate the STPP, and a suggestion for further research.
\end{abstract}

\title{
Intro:
}

It's not a secret- mass incarceration in America is a problem. As a country, we make up around $5 \%$ of the global population, and almost $25 \%$ of the global incarcerated population (ACLU, 'Mass Incarceration'). While there are endless aspects of the American criminal justice system that could be tackled for debate or reform at any given point in time, one of the most poignant issues facing the justice system today is the disproportionate representation of people of color. Black men can expect to experience 
incarceration in their lifetime at a rate of 1 out of $3,(A C L U)$. The Latino population is among one of the fastest growing populations to face incarceration, "and they are 2 to 3 times more likely to be incarcerated than White youth" (Seroczynski, Jobst, 2016). Women are the fastest growing population in jails and prisons, (ACLU). With all this in mind, politicians, lawmakers, and citizens alike are looking for ways to stem the flow of citizens into the criminal justice system. This is where the school-to-prison pipeline comes in to play.

\section{Issue:}

The school-to-prison pipeline (or STPP) describes the phenomenon of the correlation between school decisions, practices, and legal actions to an increase in incarceration rates of former students later in life (McCarter 2016, Mallett 2015, Gonsoulin, Zablocki, Leone 2012, Pesta 2018). These practices escalated in the 1990s, mirroring the changes occurring in the American criminal justice system at large in the same time frame. The practices adopted were often punitive, or hyper-focused on safety and 'zero tolerance' methods, such as armed security guards, security cameras, locked gates, school resource officers, and increased use of expulsions and suspensions (Deakin, Kupchik 2016).

This increased use of preventative measures and zero-tolerance tactics coincided with a marked increase in incarceration. Like the rates of incarceration, it demonstrated a disproportionate representation of minority students, lower-income students, and boys (Barnes, Motz 2018). These preventative or zero-tolerance methods are most often implemented in "urban, multicultural, inner-city environments; neighborhoods that more often struggle with poverty," (Mallett 2017). Yet while this is where they are most 
obvious and prevalent, the school-to-prison pipeline is a problem afflicting schools nationwide. When the causes, or problems most linked with the school-to-prison pipeline, are discovered or narrowed in on we can then start addressing them as a nation.

One of the more likely causes of this disparate interaction between expulsion, suspension, and legal actions and the general population of schools lies in implicit bias. When covariates are controlled (although there were many), Barnes and Motz (2018) discovered that while Black students did not misbehave or cause problems at any higher or lower rate than their White counterparts, they were referred for expulsion, suspension, or other disciplinary actions at a rate "roughly 1.759 times higher than that of White youth." In their study, they found a strong correlation between the overuse of school disciplinary actions and further involvement in the criminal justice system. With this in mind, figuring out ways to resolve the issues that lead to a school-to-prison pipeline could very easily reduce involvement of adults in the criminal justice system, with the highest impact on young Black men, since Black citizens as of 2010 made up 13\% of the United States, but $40 \%$ of the incarcerated population (Prison Policy, 2014).

\section{Theoretical Perspectives, and Methodological Approaches:}

There is no single agreed upon definition for the school-to-prison pipeline, but according to Christopher Mallett in his 2015 article, it "is best understood as a set of policies and practices in schools that make it more likely that students face criminal involvement with the juvenile courts than attain a quality education.” Other definitions include the likelihood of adulthood arrest and incarceration, or emphasize the use of expulsions and suspensions on negative life outcomes. This is still up for debate by skeptics, and debated by strict definition and extent by supporters. 
Many of these theories on the STPP are sociological or psychological in nature: such as labeling theory, control theory, and implicit bias. All of these theories are used as explanations for why students either get introduced or referred into the STPP, or how they manage to remain or get swept up in the pipeline.

Simply put, labeling theory explains that when a label or stereotype is applied to someone for long enough or by enough people, they are treated as that label and will rise or fall to that expectation, especially if the label affects their whole life (like the color of their skin). Labels can compound their weight: such as having dark skin, being expelled, and having dropped out of high school- you already have a picture of who this kid is, don't you? Pesta (2018) describes it as such, "In other words, rather than doing a bad thing, you are a bad kid." Labeling theory has its critics, though; those who argue that labeling is too hard to prove quantifiably.

Control theory posits that there are aspects of our own family, society, and morals or beliefs that control us and keep us in our place and from misbehaving. The use of control is both external and internal, in a way that we would tell ourselves "I don't want to break the rules, because then someone will tell my mom, and she'll be disappointed." With the STPP, school and the roles it fills can very well serve as an external control. School, teacher-student relationships, and high expectations from educators usually have a positive impact on students, and keep them from feeling unsafe or engaging in undesired behavior (Coggshall et al 2013).

Implicit bias, similar to false perceptions or unknown prejudices, can be described as "thoughts and feelings outside of conscious awareness and control" (ProjectImplicit, 2011). Implicit bias works by preying on stereotypes, which can be anything from race, 
ethnicity, religion, gender, and more. When you are boarding your flight, and you see a Middle Eastern man boarding the same plane as you —do you get a little uncomfortable? But you logically know otherwise, or talk yourself out of it, because you know better. If you do, that's implicit bias. That is an implicit bias that takes hold in a specific space (plane), with a specific sect of people (Middle Eastern men) and with a set worry or thought in mind (terrorism). Everyone has implicit biases, but there is a multitude of ways to combat them. Awareness of the bias and confrontation tends to be the quickest way to change the implicit bias.

Studying the STPP is varied in methodology and field. The fields of education, criminal justice, sociology, psychology, policymaking, and more overlap. Their goals and backgrounds may be different, but the focus on the criminalization of youth behavior in school generally follows the same path. Methodologically, their studies ranged from qualitative, quantitative, to mixed methods. While there is a range of methodology used, most lean more heavily on the quantitative measures, regardless of the field the researchers come from. This is a topic that requires close attention to the statistics of representation. Longitudinal studies are common, and strengthen the results. The qualitative studies serve to give a human element to the numbers, often by choosing a handful of students or teachers and interviewing them on their experience with the STPP and their opinions on how it happens and how to stop it. Oftentimes some of the most interesting results come from qualitative studies, such as the majority of teachers thinking that these harsh punishments were actually for the betterment of their own teaching efficacy (Coggshall et al 2013). These studies were generally conducted by either state or nationwide surveys, or by using data already collected by State or Federal governments. 
Some were funded or affiliated with outside programs, although most were self funded and reported no conflicting interests.

\section{Discoveries:}

Why is it happening?

Not a single study I examined revealed anything but a disproportionate impact in the use of disciplinary measures against Black students. There was not a study or data set that showed White students at disciplinary rates rivaling their Black counterparts, or proportionate to their population makeup of their schools, even when they were shown to misbehave at the same or non-significantly different rates. Common reasoning for why this is happening has been described as teachers and staff lack of knowledge of their implicit bias (Barnes, Motz, 2018) lack of sufficient teacher training and readiness (Coggshall et al 2013), labeling theory (Pesta, 2018), and perception of that punishment (Pesta, 2018).

Another prevailing theory is that our method of standardized testing has created a culture in public schools that "teaches to the test" (Mallett 2015). By doing this, the best achieving schools are rewarded with better funding and more resources. The schools have an obligation to make themselves look as successful as they can, by the measures they are given, and in doing such have been shown to expel or suspend low performing students. These students too often are "those with disabilities, certain minority groups, students living in lower socioeconomic class, and those whose first language is not English." (Mallett 2015). 


\section{Why does this carry over to later incarceration?}

The most prevailing theories set forth or reinforced by the articles I've covered have seen labeling theory to be one of the strongest explanations for the continuation of the STPP. This can be best described in Pesta's 2018 article, "In other words, rather than doing a bad thing, you are a bad kid." This has been shown to affect races differently, and labeling theory has been extensively studied in a more adult-focused criminal justice method, as well as from a focus on child development and education studies. The schoolto-prison pipeline is shown to mirror the effects of labeling later in life as well, with the example being used in Pesta's 2018 article, which demonstrates "This (...) suggests that for Blacks, the effect of being labeled in adolescence may have a strong influence on outcomes in adulthood" and that in adults, "the stigma associated with the label of "felon" was stronger for Blacks than Whites" (Pesta 2018). All of this seems to suggest that labeling is most often utilized against minorities, with the strongest impact being on Black students, who face fewer opportunities post-dropping out than their fellow dropouts who were Hispanic or White.

Perception of the punishments received is also a strong indicator of whether or not the punishments doled out will have the intended 'deterrent' quality. Pesta (2018) backed up a study of Sherman (1993) in which adults were less likely to be deterred by punishments they deemed unfair or unjust. Sherman suggested that offenders who perceived their "punishments as illegitimate" (Pesta 2018) were most likely to rebel and be defiant toward authority or the community. Pesta carries this over to the juvenile population in schools, and how Black and Hispanic students were most likely to perceive their punishments as unfair, and were therefore not deterred. White students were most 
likely to feel their punishments were justified, and so the punishments actually functioned as deterrence from further misbehavior. Pesta goes further, into suggesting that some of the disparity in punishments, presence in the STPP, and further likelihood of committing crime is due to the perception of injustice.

To what extent is the STPP targeting students of color?

When covariates were controlled in a nationally representative data set, with more than 20,000 students taking part and then followed in the next fourteen years, the longitudinal study (Barnes and Motz, 2018) found that "Black youth had odds of suspension/expulsion that were roughly 1.759 times higher than that of White youth.” This disparity was seen later in their respective arrest rates, in which Barnes and Motz found that "Black respondents had odds of arrest that were 1.529 times higher than the odds of arrest observed in White respondents." With their hypothesis in mind, of how intervention within the STPP could prevent later arrest or incarceration, they surmised that "if the probability of suspension/expulsion was equalized across Black and White students, we might expect to see as much as $16 \%$ reduction in the racial inequality in later arrest rates." Their study also backed the findings of Goff et al 2014 and Okonofua \& Eberhardt 2015, in which they suggest that the most likely cause of the disparity is during the referral stage, in which teachers "interpret patterns of misbehavior differently and more harshly for Blacks compared to Whites." They ultimately suggest that teachers and staff be made aware of their own implicit bias, and that in doing so it could see a reduction of disparate treatment, and ideally later racial inequalities in arrests.

Mallet (2017) talks on the disproportionate impact not just on students of color, but also on LGTBQ students, students with disabilities, and students from lower 
socioeconomic statuses. When these categories coincide with race and gender (Black male students, for instance), it creates an even greater likelihood of use of harsh disciplinary measures.

\section{Suggestions for Intervention}

Most policies that fall under zero tolerance nowadays do not begin with the intent to punish minority students, not explicitly. This trend in education began in the early to mid 1990's, in which policymakers', politicians', and school administrators' goal was to prevent unsafe learning environments, especially in the wake of the peak of adolescent crime (and overall national crime rates) in the mid 1990's in which the idea of a 'juvenile super-predator' took hold in the media and scared the nation. This concept was detached from the reality of juvenile crime, and was unabashedly racist- focusing on young Black men, called thugs and gang members and prone to "wilding" (Mallett 2015). Currently, the 'juvenile super-predator' concept doesn't have as strong of a hold on school administrators, who instead are more focused on interpersonal juvenile crime and school shootings. These policies are often put forth with "the best interests of young people as a focus," despite the fact that "schools remain, for almost all children and adolescents, the safest environment” (Mallett 2015).

While most articles had broad suggestions for room for improvement, such as implicit bias awareness, empathy-based training, and a removal of zero tolerance styled policies (Coggshall et al 2013, Barnes, Motz 2018, Mallett 2015, Mallett 2017, Pesta 2018, etc.), other articles focused almost exclusively on the specific moves forward that teachers, staff, administrators, and policymakers could do (Coggshall et al 2013). Mallet (2015) brings up the use of No Child Left Behind (2001) and similar movements, 
creating the push for standardized testing. The scoring system makes it more favorable for schools to punish and exclude badly behaving and low performing students in order to obtain more federal funding. He describes that those most affected by the STPP were often lower income, lower performing minority students, and that this overlap made it all the more desirable to exclude them from the attendance roles. Removing the "teaching to the test" mentality and financial incentive would serve to better support all students (Mallett 2015).

This all coincides with the Coggshall et al 2013 article, which focuses entirely on what teachers, administrators, and policy makers can do. They break it down into four goals that educators have in their role in the pipeline, and how they can be improved. They describe educator-student relationships, educator attitudes and social emotional competence, their own abilities to ensure conditions for learning, and lastly- the educator's approach to discipline. On top of suggesting that educators have more support for their students, a better relationship and managing healthy expectations with their students, keeping the students physically and emotionally safe, and disciplining them with a less punitive, deterrence-based approach, the authors acknowledge that there are serious challenges to these methods. Lack of funding, overcrowded classrooms, early burnout, and lack of capability from the school itself all serve to impede sweeping change in schooling, which, in order to "work effectively with at-risk children and adolescents cannot be done in piecemeal"' (Coggshall, et al 2013).

Coggshall et al ultimately calls for an increase in teachers of color, noting that "although nearly one half (45 per cent) of the 49 million public school students in the United States are students of color, only 18 per cent of public school teachers" are. They 
describe this as an issue, and reference Dee 2004, in which "emerging research suggests that, all things being equal, teachers of color are more effective with students of color in promoting student academic achievement that their white counterparts." The authors do acknowledge the difficulty in recruiting young people of color into the teaching field, due to "a vicious cycle, the lack of teacher role models that look like these students and the lack of inspiring teacher who are well prepared to meet the needs of diverse learners also play important roles in the lack of interest among students of color to enter teaching and subsequently school leadership." While the authors would suggest an increase in teachers of color, they describe the necessary traits in a comprehensive teacher, stating that "such skills are not a given and teachers of all backgrounds need solid preparation, induction and ongoing support to ensure that they have the necessary capacities to block the pipeline."

\section{Local Programs:}

There are many programs local to Oregon and the Pacific Northwest that function to help stem the flow from school to later incarceration. Many of these programs, like Oregon Youth Authority, Multnomah County's Department of Community Justice, and Clackamas County's Juvenile Department, and more, aren't able to intervene in schools themselves. Instead, their goals are to intervene right after criminal justice involvement, and prevent youth from being further sucked into the pipeline.

Oregon Youth Authority's (OYA) Youth Justice Project is focused on the criminalization of young adults, on topics like Measure 11 (mandatory minimum sentencing for select crimes) and researching what children are being criminalized most

and what can be done to prevent it. After researching, they lobby and promote changes by 
initiating "informed policy, litigation, and programmatic recommendations" (Youth Justice Project). OYA stands against perceived unethical, unconstitutional, and unjust sentencing for youth.

Multnomah County's Department of Community Justice provides numerous resources to victims and youth offenders, with an overarching goal to "address the underlying issues that drive crime" (Dept. of Community Justice). Their mission statement of providing resources and programs "guided by evidence-based strategies" (Dept. of Community Justice) allows them to reach more people, and ideally intervene before youth commit crime or fall into high risk situations (such as family separations, divorces, and incarcerated parents). The use of pulling the community together in prevention also serves as a good locus for control theories, which have been shown to keep youth from misbehaving or acting out (Coggshall et al 2013).

Also falling under control theory is the Juvenile Department through Clackamas County. More so than Multnomah County's Department of Community Justice, the Juvenile Department of Clackamas County serves to engage youth offenders. Once youth have been processed through the initial levels of the criminal justice system, they seek to build accountability for their youth, help the youth feel connected to their communities and give the youth chances to "take part in meaningful service-learning work projects" (Juvenile Department). This approach serves to both have kids own up to their mistakes, and reconnect them to the community at large, both of which are larger scale versions of the suggestions in Coggshall et al 2013.

The Janus Youth Program in Portland possesses a Juvenile Reception Center for youths who are picked up for status offenses and low-level misdemeanors, such as 
running away, truancy, curfew violation, and trespassing (Janus Youth Programs). These status offenses or low-level misdemeanors could up putting youths in 'secure confinement,' and the Janus Youth Programs seek to intervene in the use of these policies. They are partnered with the Portland Police Department, Multnomah County's DHS, and the Department of Community Justice's Juvenile Services Division. This group effort keeps kids out of more severe punishments, offers crisis counseling, and provides a safe waiting place for youth to reunite with their families.

The Oregon Youth Development Council has a collection of dozens of programs aimed at intervening with youth who have dropped out, connecting students with help in order to graduate high school, preparing students for the workforce, students in the foster care system, homeless and runaway youth, LGBTQ+ students, and those already involved in the criminal justice system, gangs, or the STPP (Oregon Youth Development Council). Many of these programs, and the Oregon Youth Development Council, are funded in part by the Title II Formula Grant Program or by the Office of Juvenile Justice and Delinquency Prevention.

The Oregon Outreach Inc. is a multi-award winning program that serves to provide educational assistance to adults and children in the Portland area in order to earn their high school diploma or GED. They are partnered with several academies, and have accredited teachers at their disposal despite there not being a requirement for 'alternative schools' to have licenses teachers in the state of Oregon. OOI creates specialized and personalized curriculums for their students, in order to get their diplomas and further their odds of success and increase their options for employment later in life. 
All of these programs attack different aspects that revolve around the school-toprison pipeline, and with their presence and the cooperation of schools, police departments, and more, there is a much better chance of children not going straight from the classroom to the cell.

\section{Conclusions and Future Research:}

Massive changes need to take place in this clearly flawed system. The school-toprison pipeline is disproportionately affecting Black and Hispanic kids. These are the students who are the victims of a system that has continuously worked against the betterment of minority and vulnerable students.

To start making a difference, changes will need to be implemented at several points on the school-to-prison pipeline. For frontloading the solution, I suggest following much of the guidelines set forth in Coggshall et al 2013: promoting educator-student relationships, having high but supportive standards, creating an emotionally and physically safe classroom, and encouraging more people of color to become teachers. I would also suggest implicit bias training, and increased awareness for educator and administrator prejudice.

Unfortunately, even if the school-to-prison pipeline was dismantled from the roots in schools around the country, it will still have certainly damaged thousands of other kids that weren't lucky enough to be part of the change. Kids who have gotten suspensions, expulsions, dropped out, or gotten involved in the criminal justice system will also need help. That is where it is important for organizations like Oregon Youth Authority and Clackamas County's Juvenile Department to step up and fill in the gap. These programs 
can help create systematic change at the criminal justice level, and reintroduce youth into a community that they felt separated from.

There is a lot that can be done about the school-to-prison pipeline. Through studies, papers, and analysis, we already know much of what we should be doing. All it takes is funding, dedication, and a commitment to evidence-based practices. Further research will always be necessary to help refine our methods and approaches. It is clear that more study needs to go into the roles of educators in intervening in the STPP, as well as qualitative research into the personal stories of those affected by the STPP. It is imperative that we as a society intervene in the STPP, because the way we are going is not sustainable. 


\section{Bibliography:}

Barnes, J. C., \& Motz, R. T. (2018). Reducing racial inequalities in adulthood arrest by reducing inequalities in school discipline: Evidence from the school-to-prison pipeline. Developmental Psychology,54(12), 2328-2340. doi:10.1037/dev0000613

Coggshall, J. G., Osher, D., \& Colombi, G. (2013). Enhancing Educators Capacity to Stop the School-to-Prison Pipeline. Family Court Review, 51(3), 435-444. doi: $10.1111 /$ fcre. 12040

Deakin, J., \& Kupchik, A. (2016). Tough Choices: School Behaviour Management and Institutional Context. Youth Justice,16(3), 280-298. doi:10.1177/1473225416665610

Department of Community Justice. (2019, May 10). Retrieved from https://multco.us/dcj

Gonsoulin, S., Zablocki, M., \& Leone, P. E. (2012). Safe Schools, Staff Development, and the School-to-Prison Pipeline. Teacher Education and Special Education,35(4), 309319. doi:10.1177/0888406412453470

Initiative, P. P. (n.d.). Breaking Down Mass Incarceration in the 2010 Census. Retrieved from https://www.prisonpolicy.org/reports/rates.html

Juvenile Department. (n.d.). Retrieved from https://www.clackamas.us/juvenile

Mallett, C. A. (2015). The School-to-Prison Pipeline: A Critical Review of the Punitive Paradigm Shift. Child and Adolescent Social Work Journal,33(1), 15-24.

doi:10.1007/s10560-015-0397-1

Mallett, C. A. (2017). The School-to-Prison Pipeline: Disproportionate Impact on Vulnerable Children and Adolescents. Education and Urban Society,49(6), 563-592. doi:10.1177/0013124516644053

Mass Incarceration. (n.d.). Retrieved from https://www.aclu.org/issues/smartjustice/mass-incarceration

McCarter, S. (2016). The School-to-Prison Pipeline: A Primer for Social Workers. Social Work,62(1), 53-61. doi:10.1093/sw/sww078

Pesta, R. (2018). Labeling and the Differential Impact of School Discipline on Negative Life Outcomes: Assessing Ethno-Racial Variation in the School-to-Prison Pipeline. Crime \& Delinquency,64(11), 1489-1512. doi:10.1177/0011128717749223

Programs for the runaway youth at Janus. (n.d.). Retrieved from http://www.janusyouth.org/programs/runaway-youth 
ProjectImplicit. (2011). Retrieved from https://implicit.harvard.edu/implicit/aboutus.html

Resources. (n.d.). Retrieved from

http://www.oregonyouthdevelopmentcouncil.org/resources/

Seroczynski, A. D., \& Jobst, A. D. (2016). Latino Youth and the School-to-Prison Pipeline. Hispanic Journal of Behavioral Sciences,38(4), 423-445.

doi: $10.1177 / 0739986316663926$

Who is OOI \& Our Mission to Oregon Youth | Oregon Outreach Inc. (2018, June 06).

Retrieved from https://oregonoutreach.org/who-is-oregon-outreach/

Youth Justice Project. (n.d.). Retrieved from https://ojrc.info/youthjusticeproject 